\title{
Word of mouth, trust, satisfaction and effect of repurchase intention to Batavia hospital in west Jakarta, Indonesia
}

\author{
Endang Ruswantia ${ }^{*}$, Aprilita Rina Yanti Eff ${ }^{\mathrm{b}}$ and Medina Diyah Kusumawatic
}

${ }^{a}$ Department of Economic, Esa Unggul University Jakarta, Indonesia

${ }^{b}$ Department of Pharmacy, Esa Unggul University Jakarta, Indonesia

'Department of Psychologyst, Atma Jaya University Jakarta, Indonesia

\section{H R O N I C L E}

Article history:
Received: June 242019
Received in revised format: July
282019
Accepted: September 3, 2019
Available online:
September 3, 2019
Keywords:
WOM
Trust
Compliance
Intention Repurchase Hospital

\section{A B S T R A C T}

Word of mouth (WOM) advertisement plays an essential role for business development. WOM helps consumers become familiar with new products and services, the quality of services and promotes different choices with possibly better features. This paper examines the effect of word of mouth advertisement in medical treatments in Batavia hospital in west Jakarta, Indonesia. The study examines the effects of WOM on patient's fulfillment, satisfaction and re-admission in this hospital. The study designs a questionnaire and distributes it among some patients who are waiting to receive medical care at this hospital. The survey only concentrates on patience who used the medical treatment for at least two times. Structural equation modeling is used to examine the hypotheses of this survey. The results indicate that WOM could increase the patience's awareness and positively influence on patience's choice for getting more treatment.

\section{Introduction}

The word of mouth (WOM) industry has been experiencing huge growth since 2004. The Word Mouth Marketing Association (WOM) has grown naturally from three to three hundred and fifty members of the local company (WOM, 2007). Research estimates that while $90 \%$ of WOM conversations take place online (Keller \& Berry, 2006), only $15 \%$ of consumers take that into account. The existing interpersonal communication theory is not appropriate to describe WOM behavior online. Emotional properties in communication are mediated by computers based on principles in social cognition and interpersonal relationships for the development of social psychology (Lea \& Spears, 1995; Parks \& Floyd, 1996; Walther, 1992, 1996). The advice from individuals to form impressions with others is based on the contents of electronic newspapers. The importance of marketers is to understand how impressions affect the assessment based on WOM. Many scholars are interested in WOM communication behavior. Behavior in the context of the online community is due to its popularity, growth, and tremendous influence from the community of transmissible people. Online communities have a limited communal presence and traditional community provides information and social support, both specifically and widely complementing social and customer behavior (Wellman et al., 1996). Word of mouth communication is precisely a consumer-dominated marketing channel, and conversation is considered to be more trustworthy, credible, and dependable on critical consumers (Schiffman \& Kanuk, 2010; Arndt, 1967). Traditional communication theory considers WOM to possess a powerful influence on social behavior, especially on consumer information seeking, evaluation and subsequent decision making (Cox, 1983; Brown \& Reingen, 1987; Mony et al., 1998; Silverman, 2001). It provides information about the product and social performance, psychological consequences of purchasing decisions (Cox, 1983). WOM can positively affect the levels of cognition and lead to committed behavior (Bristor, 1990). WOM's credibility, when it is suitable can form a higher-order in beliefs and cognitions. Through many exchanges, WOM provides potential news (Lau \& Ng, 2001). The outcome of interpersonal exchanges obtains the * Corresponding author.

E-mail address: endang.ruswanti@esaunggul.ac.id (E. Ruswanti) 
provision of access, consumption-related information that holds some information value for formal promotion. The advertising message adequately conveyed by the company influences consumer decision making. Excellent communications are characterized by the feeling that closeness and unique relationships are based on a sense of friendship, interest in interaction often in many cultural contexts, mutuality relations because of the prospective consumers' needs (Walker et al., 1994). The published results of several researchers show that the power of WOM can be considered as a reliable information. The purpose of the study is (1) to examine the effect of word of mouth on pleasure (2) to test trust in satisfaction (3) satisfaction test with the intention of re-admission at the hospital in West Jakarta. The specific purpose of this study is for the public to understand the information provided by individuals through word of mouth to facilitate evaluation in decision making.

\section{Literature review}

\subsection{Word of mouth, trust, satisfaction and intention of purchase}

Word of mouth technique is considered to affect patient satisfaction when a sick person's hospital is satisfied with the treatment and disseminate this information to others. Those who seek treatment routinely describe their experiences when examined or operated on by a doctor. The accurate information adequately conveyed by friends, family, and acquaintances is an origin of personal suggestions (Brown \& Reingen, 1987; Duhan et al., 1997) popularly known as the basis of WOM. Newspapers, articles, and comments submitted by journalists, columnists, consumers and, experts can be found in magazines, special publications and online discussion forums as sources of impersonal advices. Information systems and discussion forums are included as sources of personal recommendations (Senecal et al., 2005) because they are influenced by product choices online with recommendations addressed online (Senecal \& Nantel, 2004). Consumers receive commercial information and appreciate the intent of marketing promotion behind the statement as a recommendation, but this type communication is not word of mouth since word is associated with a private conversation between someone who voluntarily provides information with prospective customers who require information.

Word-of-mouth is commonly defined as the cultural exchange, continuous flow of accurate information, effective communication, or personal dialogue between two individuals. There is typically only one researcher (Haywood, 1989) who regards word-of-mouth as a formal conversation. Other researchers agree that word of mouth is merely an informal and noncommercial conversation. The term "informal" refers to something that is officially unregulated in Paridon (2008). Besides, WOM communication is sometimes defined as post-purchase behavior. Besides, giving to the previous work, for consumers for related communications in WOM, messages stored, and media employed for spreading cannot be carried out by the company (Silverman, 2001). For example, can the context of e-services where many corporations have discussion forums on their independent sites? In fact, in recent research, such forums are expected a source of WOM as long as consumers consider this connection to be very informal and not sponsored or subsidized by the company. According to Silverman (2001), other types of communication are famous and formal because of advertising and the public.

\section{$\mathrm{H}_{1}$ : Word of mouth has a significant effect on patient's fulfillment.}

Patient trust and pleasure are closely related, that by believing in the seller of services, satisfied consumers will return to treatment again. The published results of the study by Lu et al. (2010) show that trust has an influence on patient satisfaction, and satisfaction positively affects the intention to repurchase. All WOM communications occur precisely in social relations that can be typically categorized between news seekers and information sources represented by loyal customers who have experience (Money et al., 1998; Duhan et al., 1997; Bristor, 1990). The power of information is a multidimensional construction that represents the source and has the authority of interpersonal relationships or the context of social networks (Money et al., 1998) and includes closeness, familiarity, support, and associations (Frenzen \& Davis, 1990). Frequency of conversation and intimacy of exchanges between information providers and information searchers are also essential (Marsden \& Campbell, 1984; Hartlines \& Jones, 1996).

$\mathrm{H}_{2:}$ Patient's trust exerts a significant effect on patient's satisfaction.

There are enormous potential benefits of favorite word-of-mouth. WOM represents a tool for managers who wish to assess the representation of their businesses. Word of mouth can be employed to predict customer purchase intentions and tendencies to convey information to speak well about the company (Arndt, 1967; Brown \& Levinson, 1987; Maxham-III, 2001; Ying \& Chung, 2007). In Indonesia, word of mouth is called chain communication, but outside Indonesia, it is called word of mouth. Some previous researchers mentioned that word of mouth affects patient's satisfaction in treatment at hospitals. Word of Mouth communication can result in face to confront, via mobile, mobile phone, e-mail, mailing list, or other means of association (Silverman, 2001; Haywood, 1989; Godes \& Mayzlin, 2004). Erkan and Evans (2016) explained that argument quality, sour credibility, requirements of information, opinion towards details, information usefulness, information adoption may influence on repurchase intention.

$\mathrm{H}_{3}$ : Patient's fulfillment possesses a significant effect on the idea of re-admission. 


\section{Research Methods}

\subsection{Population and Sample}

The population of this study included all patients of the hospital in West Jakarta, and the population was considered unknown. The manner of retrieval of data uses purposive sampling, with responders having been inspected at the medical center west in Jakarta. This study was presented in the type of study carried out at the hospital in West Jakarta through a question sheet. The questionnaire was adapted from a conceptual framework to represent the aspects of word of mouth, trust, satisfaction, and repurchase effects to help survey design. The expansion of survey items is established on the literature review of previous research and considers the elements that influence word of mouth in end-of-treatment to the medical center so that it could be made known through a research survey. Factor analysis is utilized to recognize displays from the elements of word of mouth variables, including trust, achievement, and repurchase intention.

The data point was analyzed using structural equation modeling (Hair et al., 2006) to find the elements and produce the outcomes of construct validity, from the dimension indicator of word of mouth. It was first tested through Bartlett's roundness in the statistical correlation test between variables and the Kaiser-Meyer-Olkin test to consider at the sample adequacy measures applied to test factor analysis. KMO possesses a benefit that passes the minimum value of 0.60 (Hair et al., 2006). Bartlett's analyzes the influence of the significance of all factors. Likert scale has been used to answer the research statements and to confirm the results to be achieved. Al-Khattab et al. (2015) state that consumers show various degrees about the intention to buy and purchase behavior.

The object of the study was associated with the customers of the Hospital in West Jakarta who had inspected the hospital twice. Research was in the form of a survey and data were obtained through collecting questionnaires distributed to respondents. The research responders remain, 114 people, the process of data collection used purposive sampling, namely sufferers who had come twice to attend to the Batavia Hospital in West Jakarta. To emphasize, not many words of mouth studies have been studied at the Batavia Hospital in West Jakarta, interviews were conducted to check through 30 respondents before data evaluation needed to be tested to determine validity and reliability using factor analysis.

\subsection{Research Variable Measurement}

The research variable consisted of independent variables of word of mouth with four dimensions. First, the intensity of word of mouth was taken on from: discuss this hospital more often, talk about the hospital with many individuals, talk about hospitals through social media, etc. Both positive valences of word of mouth: talked about the high side of the hospital, proud to inform them, a customer of a hospital, typically announce beneficial things to others. Negative valence third: generally, declare negative things to others, want to complain to the doctor to explain the disease in detail. The quartet piece of word of mouth: discuss the hospitality of health center website users, discuss the quality of the various services offered. Trust variable: trust hospital, discuss the security of transactions at infirmaries, believe in hospital commitment, believe the hospital has successfully sold services, talk about hospital fame. The wish of patients to come back to the clinic depends on the satisfaction of the hospital in providing services. The satisfaction variable includes hospitality in service and cost. Dependent variable intention to readmission treatment: intend repeating the treatment at this hospital, strongly recommend that people pursue treatment at this hospital. The questionnaire was adopted with necessary modification from (Goyette et al., 2010), and the research signs make 20 specific items.

\section{Result and Discussion}

The liableness of the model can be tested by calculating construct reliability and extracted difference. The calculation results from construct dependability and difference are extracted by Hair et al. (2006) and the condition of excellent reliability is to have the reliability constructed equal to 0.70 and variance extracted equal to 0.50 . The calculation results show that not all questionnaires in each variable meet the reliability requirements adequately. The value of word of mouth construct reliability was (0.93), confidence in (0.92), satisfaction (0.96), and intention to seek treatment was (0.62). Furthermore, the values of difference extracted for WOM, trust, satisfaction and intension to re-admission were $0.60,0.72,0.85$ and 0.45 , respectively with variance extracted to be equal to 0.50 . The Chi-Square test also shows the goodness of the fit. RMSA value $<0.05(0.036)$ shows the match is good fit. Confidence intervals are used to evaluate the exhibition of the RMSEA approximate calculation and the results also confirm the proposed model. Other statistics also demonstrate the goodness of the fit (See Table 1 in Appendix). Fig. 1 demonstrates the summary of the results. The effect of WOM on consumer acquisition intentions has already been investigated by Hajli (2015) and Lu et al. (2010). Even the impact of word of mouth on social media on consumer acquisition intentions has also been investigated by Wang et al. (2012). However, this study presented significant results that WOM influenced the intention of repurchase at the Hospital in West Jakarta through mediating sick person satisfaction in treatment. In this survey, the sufferer's opinions positively affect the intention of repurchase through patient satisfaction. Actually, in Indonesia, WOM is performed by virtually a number of patients who are remaining for a physician's inspection when they stay in the health center. They traditionally named it as "Getok Tular", meaning that fellow patients wanted to talk 
about their experiences about their sicknesses and how to cure the disease. Moreover, in waiting for the serial number, discussion with the treating doctor, medications which are given by the doctor, the consequences of surgery, contraindications to the medication given by the doctor, etc. Occasionally hospitals do imperfectly understand communication between patients, even though the most effective communication represents information from others who have experienced it first. If the communication is positive, the hospital will receive benefits, but if the communication is negative, then the hospital will suffer losses.

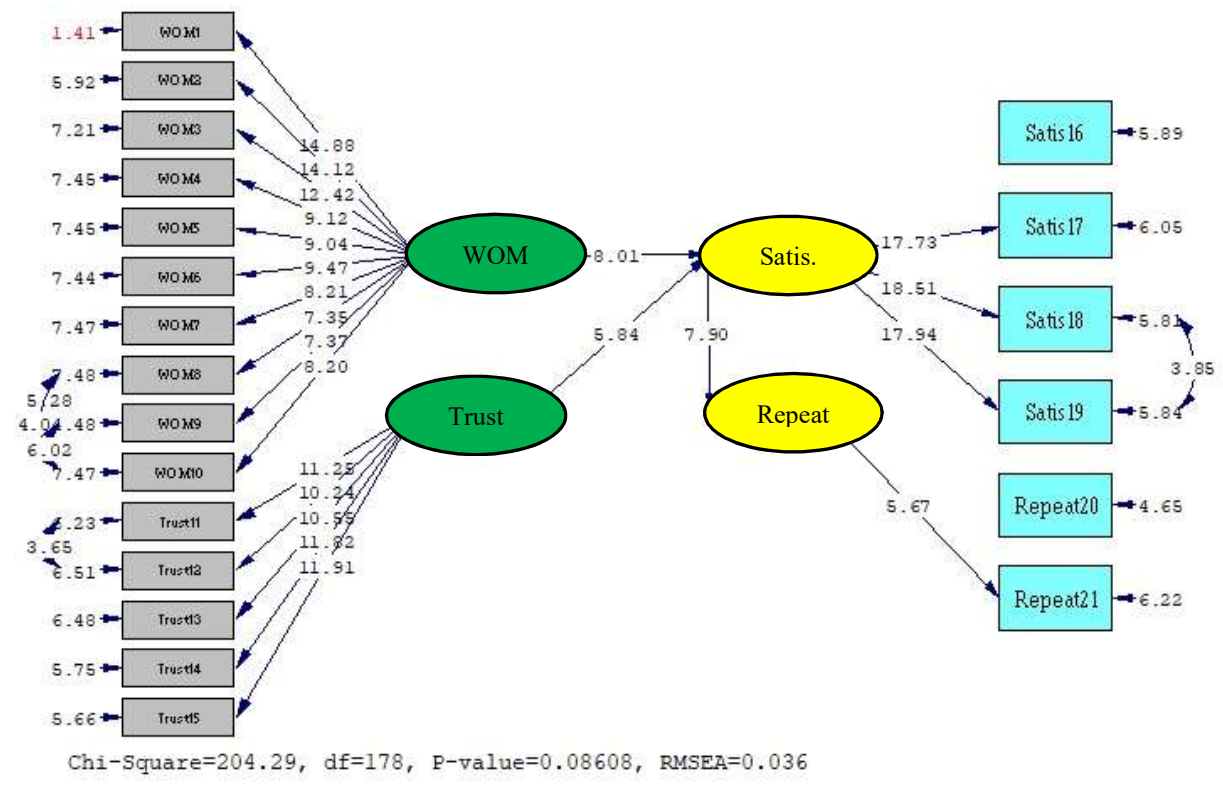

Fig. 1. Path Diagram (T. Value)

According to Ruswanti (2013), cherry-picking, shopping satisfaction concerning maven market was significant. Market maven is defined as someone who frequently possesses the knowledge and voluntarily communicates to people in need. They do not receive a fee from the Batavia hospital and are not rewarded by drug manufacturers or other social institutions. So, if compared, there is a likeness between maven market with word of mouth. On another occasion, the opportunity to test the maven market with word of mouth can be performed. According to Lester et al. (2012), Ruvio and Aviv (2007), maven functions as social media. Shopping satisfaction produces a significant effect on the maven market. While Paridon (2008) reasonably argues that users trust more news conveyed by humans than information through the health center in the specific form of paid advertisements. In fact, ordinary consumers receive word of mouth and e-WOM information from colleagues, office friends, neighbors, partners, and relatives. There is a relationship between WOM and consumer decision making in buying hospital services, but various factors can deliver alternative results to the theory. Consequences positively related to the unique characteristics of WOM information related to previous theories, and their consequences are excellent or negative from the helpfulness of the information. This study looks at the factor of re-purchase intention for re-treatment evaluation as the dependent variable.

\section{Conclusions}

This study has proposed a research model to properly test the influence of word of mouth on the kind intention of re-admission at the Hospital in West Jakarta. The consequences of evaluating the first hypothesis presented that word of mouth had significant effect on sick person. The dominant influence was typically word of mouth with the intention of repeated treatment mediated by patient's pleasure. While the belief in the satisfaction of sick people with pain significantly indicates acceptance of the second hypothesis. The results have shown that word of mouth, and hospital patient confidence had significant effects on satisfaction and had significant effects on the intention to repeat the treatment at the hospital. Thus, the third hypothesis was accepted. The suggestion is that hospitals need to raise word of mouth being composed of word of mouth intensity, satisfied valences, negative valence, and word of mouth content because it is proven to increase the intention to attend to patients. The direct results of the study made known some theoretical and managerial. However, the significant contribution of this study was to understand the social influence between independent variables of word of mouth consisting of four dimensions. The limitation of the analysis and the direction of intended research on the results of the study should be considered. First, the number of respondents need to be expanded and a sample taken representing twenty-seven provinces in Indonesia so that research results can be generalized. The study has not tested word of mouth in terms of the quality of the argument and the credibility of information is related to attitudes towards information in the intention to repurchase. Finally, future research can develop this research by adding variables or using this model by adding different variables, like argument quality, 
needs of information and attitude towards information. There are some managerial implications for this study. The hospital managers should maintain deep care of them because patients who have been dealt with and received excellent service commonly inform prospective patients about their experience of being examined by doctors or surgery. The sick person's trust in the hospital affects the patient's satisfaction and then intends to rehearse treatment. Positive information has an impact on prospective patients. They have an idea of deciding to aim treatment at a hospital, and doctors will choose who will handle the complaint. Word of mouth affects patient satisfaction by feeling satisfied and then providing positive information to prospective hospital patients. For this reason, with increased satisfaction, patients will intend trying treatment again.

\section{Acknowledgment}

We thank to the Ministry of research and Higher Education the Government of Indonesia for funding this research. The authors also would like to thank the anonymous referees for constructive comments on earlier version of this paper.

\section{References}

Al Khattab, S. A., As'ad, H., \& Zaidan, G. M. (2015). E-Integrated marketing communication and its impact on customers' attitudes. American Journal of Industrial and Business Management, 5(08), 538.

Arndt, J. (1967). Role of product-related conversations in the diffusion of a new product. Journal of Marketing Research, 4(3), 291-295.

Bristor, J. (1990). Exhanced explanations of word of mouth communications; the power of relations. Research in consumer behavior, 4, 51-83.

Brown, P., \& Levinson, S. C. (1987), Politeness: Some universals in language usage (Rev. ed.). Cambridge, UK: Cambridge University Press.

Brown, J. J., \& Reingen, P. H. (1987). Social ties and word-of-mouth referral behavior. Journal of Consumer research, 14(3), $350-362$

Cox, A., Granbois, D., \& Summers, J. (1983). Planning, search, certainty and satisfaction among durables buyers: a longitudinal study. ACR North American Advances.

Erkan, I., \& Evans, C. (2016). The influence of eWOM in social media on consumers' purchase intentions: An extended approach to information adoption. Computers in Human Behavior, 61, 47-55.

Duhan, D. F., Johnson, S. D., Wilcox, J. B., \& Harrell, G. D. (1997). Influences on consumer use of word-of-mouth recommendation sources. Journal of the Academy of Marketing Science, 25(4), 283.

Frenzen, J. K., \& Davis, H. L. (1990). Purchasing behavior in embedded markets. Journal of Consumer Research, 17(1), 112.

Godes, D., \& Mayzlin, D. (2004). Using online conversations to study word-of-mouth communication. Marketing Science, 23(4), 545-560.

Goyette, I., Ricard, L., Bergeron, J., \& Marticotte, F. (2010). e-WOM Scale: word-of-mouth measurement scale for e-services context. Canadian Journal of Administrative Sciences/Revue Canadienne Des Sciences de l'Administration, 27(1), 5-23.

Hair, J. F., Black, W. C., Babin, B. J., Anderson, R. E., \& Tatham, R. L. (2006). Multivariate data analysis (Vol. 6). Upper Saddle River, NJ: Pearson Prentice Hall.

Hajli, N. (2015). Social commerce constructs and consumer's intention to buy. International Journal of Information Management, 35(2), 183-191.

Hartline, M. D., \& Jones, K. C. (1996). Employee performance cues in a hotel service environment: Influence on perceived service quality, value, and word-of-mouth intentions. Journal of Business Research, 35(3), 207-215.

Haywood, K. M. (1989). Managing word of mouth communications. Journal of Services Marketing, 3(2), 55-67.

Keller, E., \& Berry, J. (2006). Word-of-mouth: The real action is offline. Advertising Age, 77(49), 20.

Lea, M., \& Spears, R. (1995). Love at first byte? Building personal relationships over computer networks. In J. T. Wood and S. Duck (Eds.), Under-studied relationships: Off the beaten track (pp. 197-233). Thousand Oaks, CA: Sage

Lester, D., Tudor, R. K., Loyd, D. D., \& Mitchell, T. (2012). Marketing Mavens' fusion with social media. Atlantic Marketing Journal, 1(1), 6.

Lau, G. T., \& Ng, S. (2001). Individual and situational factors influencing negative word-of-mouth behavior. Canadian Journal of Administrative Sciences/Revue Canadienne Des Sciences de l'Administration, 18(3), 163-178.

Lu, Y., Zhao, L., \& Wang, B. (2010). From virtual community members to C2C e-commerce buyers: Trust in virtual communities and their effect on consumers' purchase intention. Electronic Commerce Research and Applications, 9(4), 346-360.

Marsden, P. V, \& Campbell, K. E. (1984). Measuring tie strength. Social Forces, 63(2), 482-501.

Maxham III, J.G. (2001). Service recovery's infl uence on consumer satisfaction, positive Word-of-Mouth, and purchase intentions. Journal of Business Research, 54(1), 11-29.

Paridon, T. (2008). Consumer self-confidence and patronage intensity heuristics in shopping focused word of mouth communication. Marketing Management Journal, 18(1), 84-99.

Parks, M. R., \& Floyd, K. (1996). Making friends in cyberspace. Journal of Communication, 46, 80-97.

Ruswanti, R. (2013). Cherry pick shopping satisfaction and market maven. Journal of Economics Business and Accounting Ventura, 16(2), 289-298. 
Ruvio, A., \& Shoham, A. (2007). Innovativeness, exploratory behavior, market mavenship, and opinion leadership: An empirical examination in the Asian context. Psychology \& Marketing, 24(8), 703-722.

Schiffman, L.G., \& Kanuk, L.L. (2010). Consumer behavior (10thed). Upper Saddle River, NJ: Pearson Education

Senecal, S., Kalczynski, P. J., \& Nantel, J. (2005). Consumers' decision-making process and their online shopping behavior: a clickstream analysis. Journal of Business Research, 58(11), 1599-1608.

Senecal, S., \& Nantel, J. (2004). The influence of online product recommendations on consumers' online choices. Journal of retailing, 80(2), 159-169.

Silverman, G. (2001), The Secrets of Word-of-Mouth Marketing: How to Trigger Exponential Sales Through Runaway Wordof-Mouth. New York: American Marketing Association.

Wang, X., Yu, C., \& Wei, Y. (2012). Sosial media peer communication and and impacts on purchase intention a consumer and socialization framword. Journal of Interactive Marketing 26(4), 198-208.

Walker, M., Wasserman, S., \& Wellman, B. (1994). Statistical Models for Social Support Networks, Advances in Social Network Analysis, Research in the Social and Behavioral Sciences. Sage, Thousand Oaks.

Walther, J. B. (1992). Interpersonal effects in computer-mediated interaction: A relational perspective. Communication research, 19(1), 52-90.

Walther, J. B. (1996). Computer-mediated communication: Impersonal, interpersonal, and hyperpersonal interaction. Communication Research, 23, 1-43.

Wasserman, S., \& Wellman, B. (1994). Statistical Models for Social Support Networks, Advances in Social Network Analysis, Research in the Social and Behavioral Sciences. Sage, Thousand Oaks.

Wellman, B., Salaff, J., Dimitrova, D., Garton, L., Gulia, M., \& Haythornthwaite, C. (1996). Computer networks as social networks: Collaborative work, telework, and virtual community. Annual review of sociology, 22(1), 213-238.

Ying, H.L., \& Chung, C.M. (2007). The effects of single-message single-source mixed Word-of-Mouth on product attitude and purchase intention. Asia Pacifi c Journal of Marketing and Logistics, 19(1), 75-93.

\section{Appendix}

The results of the analysis show that the goodness of fit in this research model obtains such as:

Table 1

Goodness of Fit

\begin{tabular}{|c|c|c|c|}
\hline Group & Indicator & Value & Keterangan \\
\hline 1 & Degree of Freedom & 178 & \multirow{4}{*}{ Good to fit } \\
\hline & Chi-Square & 227.93 & \\
\hline & NCP & 26.29 & \\
\hline & Confidence Interval & $0.0 ; 65.80$ & \\
\hline \multirow[t]{3}{*}{2} & RMSEA & 0.036 & \multirow{3}{*}{ Close to fit } \\
\hline & Confidence Interval & $0.0 ; 0.057$ & \\
\hline & P-Value & 0.85 & \\
\hline \multirow[t]{4}{*}{3} & ECVI Model & 2.75 & \multirow{4}{*}{ Good to fit } \\
\hline & ECVI Saturated & 4.09 & \\
\hline & ECVI Independence & 79.90 & \\
\hline & Confidence Interval & $2.51 ; 3.10$ & \\
\hline \multirow[t]{6}{*}{4} & AIC Model & 310.29 & \multirow{6}{*}{ Good to fit } \\
\hline & AIC Saturated & 462.00 & \\
\hline & AIC Independence & 9028.35 & \\
\hline & CAIC Model & 508.31 & \\
\hline & CAIC Saturated & 1325.06 & \\
\hline & CAIC Independence & 9106.81 & \\
\hline \multirow[t]{6}{*}{5} & NFI & 0.97 & \multirow{6}{*}{ Good to fit } \\
\hline & CFI & 0.99 & \\
\hline & NNFI & 0.99 & \\
\hline & IFI & 0.99 & \\
\hline & RFI & 0.97 & \\
\hline & PNFI & 0.83 & \\
\hline 6 & Critical $\mathrm{N}$ & 112.45 & Marginal to fit \\
\hline \multirow[t]{4}{*}{7} & Standardized RMR & 0.047 & \multirow{4}{*}{ Good to fit } \\
\hline & GFI & 0.85 & \\
\hline & AGFI & 0.81 & \\
\hline & PGFI & 0.66 & \\
\hline
\end{tabular}

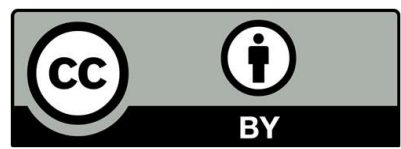

(C) 2020 by the authors; licensee Growing Science, Canada. This is an open access article distributed under the terms and conditions of the Creative Commons Attribution (CCBY) license (http://creativecommons.org/licenses/by/4.0/). 